\title{
Flotation study on low-grade antimony ore of qilla abdullah, balochistan, pakistan
}

\author{
M. A. Bhatti ${ }^{* 1}$, K. R. Kazmi ${ }^{1}$, A. Mehmood ${ }^{1}$, R. Mehmood ${ }^{1}$, A. Ahad ${ }^{2}$ and A. Akram ${ }^{1}$ \\ ${ }^{1}$ Mineral Processing Research Centre, PCSIR Laboratories Complex, Ferozepur Road, Lahore-54600, Pakistan \\ ${ }^{2}$ Government Islamia College, Civil Lines, Lahore, Pakistan
}

\begin{abstract}
A low-gradeantimony deposit originating from district Qilla Abdullah, Balochistan Province of Pakistan, containing stibnite as an economical mineral was beneficiated by froth flotation technique. Flotation parameters such as particle size of the feed, pulp density, $\mathrm{pH}$ of the pulp, agitation speed, type and dose of reagents (i.e. collector, frother, activator, regulator and modifier) and the conditioning time were studied on the basis of single-factor variation experiment in order to get the optimum grade and recovery. Regrinding of the rougher concentrate followed by cleaning andrecleaning of rougher concentrateensured a final concentrate grade of $65.12 \% \mathrm{Sb} @ 85.79 \%$ recovery. This concentrate is suitable for the extraction of metal and production of chemicals.
\end{abstract}

Keywords: Antimony ore; Stibnite mineral; Beneficiation; Flotation; Grade; Recovery

\section{Introduction}

Antimony ( $\mathrm{Sb}$ ) is a silvery-gray metal. Its average concentration in the earth's crust is about $0.3 \mathrm{ppm}$. It rarely occurs in nature in free metallic state and combines with other elements to forms different types of minerals. Its most important mineral is known as stibnite $\left(\mathrm{Sb}_{2} \mathrm{~S}_{3}\right)$ which is the main source of antimony metal and its compounds. Antimony also occurs as complex sulphides in association with silver, copper and lead ores. It is obtained economically as by-product during smelting of these ores (Blackburn, 1988; Berger, 1993).

Stibnite sometime weathers to various oxides minerals which are of less commercial importance. Low-grade antimony ores need processing for an increase in metallic grade as well as reduction of the gangue content. $\square$ There are different techniques that can be applied for beneficiation of lean antimony ores depending upon their characteristics. However, gravity concentration and flotation techniques are commonly used. Generally, gravity concentration is adopted for coarse-grained ores while froth flotation is preferred for finely disseminated ores. Sometime, gravity methods are applied for pre-concentration followed by flotation. The antimony content of either the ore or the concentrate determines the method of treatment for the recovery of metal. Ore or concentrates containing $25-45 \% \mathrm{Sb}$ are smelted in a blast furnace, while those containing more than $45 \% \mathrm{Sb}$ can be treated by iron precipitation method. The metal is further purified by fire refining or electrolytic process (Weiss, 1985).

Antimony ore deposits have been found at various localities in Pakistan. However, significant reserves occur near Qilla Viala and Haji Sardar areas in Qilla Abdullah district of Balochistan. The ore, mainly stibnite, is associated with quartz veins in quartzitic sandstone and shale of Shaigalu sandstone in Khojak Formation of Oligocene age. Hosted within the Chaman transform fault system, these occurrences, according to Sillitoe were possibly generated during faulting and the related deformation stages (Sillitoe, 1978). Light to dark brown oxidation zone, with which the mineralization is associated at the surface, is $15-70 \mathrm{~m}$ wide and extends up to $700 \mathrm{~m}$ in length. The zone of mineralization spread in about $5 \mathrm{~km}^{2}$ area along the associated fault zone. On the basis of wide oxidation zones, Ahmad (1975) reported that the favourable area is considerably large and the reserves would increase after thorough exploration.

The present study was mainly focused on development of a suitable process for beneficiation of antimony ore of Qilla Abdullah. For this purpose, the ore was investigated by froth flotation technique to produce antimony concentrate at Mineral Processing Laboratory, PCSIR, Lahore. An effort was made to study the effect of 
important variables encountered in the flotation of metallic sulphide minerals.

\section{Materials and methods}

A representative sample of the ore, consisted of lumps of various sizes, was obtained from Qilla Viala area of Qilla Abdullah district of Balochistan. It was jaw crushed to a size of 20-25 $\mathrm{mm}$ followed by roll crusher to product of 5-6 mm. A head sample for chemical analysis was obtained by coning-quartering and riffling of the crushed ore while the remaining ore was used for processing studies.

Table I. Chemical analysis of antimony ore

\begin{tabular}{ll}
\hline Constituents & Percentage \\
\hline $\mathrm{Sb}$ & 20.04 \\
$\mathrm{~Pb}$ & 0.36 \\
$\mathrm{Fe}$ & 5.32 \\
$\mathrm{~S}$ & 18.02 \\
$\mathrm{SiO}_{2}$ & 8.30 \\
$\mathrm{Al}_{2} \mathrm{O}_{3}$ & 10.08 \\
$\mathrm{BaO}$ & 11.97 \\
$\mathrm{CaO}$ & 1.83 \\
$\mathrm{Na}$ & $\mathrm{O}$ \\
$\mathrm{K}_{2} \mathrm{O}$ & 0.18 \\
\hline
\end{tabular}

The representative sample of ore was ground to pass 200 mesh sieve with the help of disc pulverizer (Denver, USA) and its chemical analysis was performed by gravimetric, volumetric and instrumental methods. Silica, alumina, lead, barium and sulphur were determined gravimetrically, while antimony by iodometric titration, iron by oxidation reduction titration, calcium and magnesium by complexometric titration. Sodium and potassium were estimated by flame photometer (PFP7, Jenway Limited, England). The chemical analysis of head sample and final concentrate is given in Table I \& IV respectively.

Flotation experiments were conducted in a flotation machine (Model: D-12, Denver, USA), using stainless steel cells of $1 \& 2$ litres capacity. The ore was ground from $70-99 \%$ passing 200 mesh $(74 \mu \mathrm{m})$ to study the effect of particle size. Flotation feeds were prepared by wet grinding of roll crusher product in rod mill (Denver, USA) with solid to liquid ratio of $1: 1$. The effect of pulp density during conditioning was studied by varying the percentage of solids from $20-35 \%$. Similarly the effect of $\mathrm{pH}$ was studied by varying it from 8.0 to 9.5 with soda ash. Impeller speed was varied from 900-1200 rpm to study the effect of agitation. Lead acetate was employed to activate stibnite mineral and its amount was varied from $500-1500 \mathrm{~g} / \mathrm{t}$. Sodium silicate was added to depress the silicate gangue minerals and its quantity was increased from 200-1000 g/t. Sodium cyanide was applied to depress associated pyrite gangue in cleaning stage and its amount was varied between 100 and $500 \mathrm{~g} / \mathrm{t}$. Potassium amyl

Table II. Antimony ore flotation parameters and conditions

\begin{tabular}{|c|c|c|c|}
\hline \multirow[t]{2}{*}{ Parameters } & \multicolumn{3}{|c|}{ Conditions } \\
\hline & Roughing & Cleaning & Re-Cleaning \\
\hline Grain size & $80 \%-200 \#$ & $98 \%-200 \#$ & $98 \%-200 \#$ \\
\hline Agitation speed (aeration) & $1100 \mathrm{rpm}$ & $900 \mathrm{rpm}$ & $900 \mathrm{rpm}$ \\
\hline Pulp density (\%solids) & $30 \%$ & $20 \%$ & $20 \%$ \\
\hline $\mathrm{pH}$ of the pulp & $\sim 9.0$ & $\sim 9.0$ & $\sim 9.0$ \\
\hline Stibnite activator (lead acetate) & $1250 \mathrm{~g} \mathrm{t}^{-1}$ & $300 \mathrm{~g} \mathrm{t}^{-1}$ & Nil \\
\hline Collector (potassium amyl xanthate) & $300 \mathrm{~g} \mathrm{t}^{-1}$ & $100 \mathrm{~g} \mathrm{t}^{-1}$ & Nil \\
\hline Frother (pine oil) & $40 \mathrm{~g} \mathrm{t}^{-1}$ & $20 \mathrm{~g} \mathrm{t}^{-1}$ & Nil \\
\hline Gangue depressant (sodium silicate) & $800 \mathrm{~g} \mathrm{t}^{-1}$ & $200 \mathrm{~g} \mathrm{t}^{-1}$ & Nil \\
\hline Pyrite depressant (sodium cyanide) & Nil & $100 \mathrm{~g} \mathrm{t}^{-1}$ & Nil \\
\hline Conditioning time & $15 \mathrm{~min}$ & $15 \mathrm{~min}$ & $5 \min$ \\
\hline Flotation time & $20 \mathrm{~min}$ & $15 \mathrm{~min}$ & $12 \mathrm{~min}$ \\
\hline
\end{tabular}


xanthate was used as principal collector with its dosage ranging from $100-500 \mathrm{~g} / \mathrm{t}$ while pine oil was utilized as frother and its dose was varied from $10-50 \mathrm{~g} / \mathrm{t}$. The results obtained were plotted against the grade and recovery of rougher concentrates and are shown graphically in figures1-9. In the end, locked cycle flotation tests were carried out. In each complete cycle, rougher concentrate and cleaner tailings (middlings) were ground and circulated back, at appropriate point, one or more processing steps to subsequent cycle tests. The optimum conditions of flotation parameters including type and quantities of reagents as well as point of addition are recorded in Table II. The metallurgical balance of the typical tests showing product distributation, grade of intermediate and final products is presented in Table III. The flow-sheet developed from locked cycle tests for preparing high-grade antimony concentrate is given in Fig. 10.

\section{Results and discussion}

It is evident from the chemical analysis presented in Table- 1 that $20.04 \%$ head grade of antimony is sufficient to exploit the ore on commercial scale for the production of antimony and antimony based chemicals (Kursun et al., 1994). The other elements present are silica, alumina, iron oxide, barium oxide, calcium oxide and lead. Flotation technique was adoptedkeeping in view its effective potential of reductionof these impurities (Bhatti et al., 2008).

The flotation method depends not only on the type of minerals but also on the grain size of mineral distributed in the ore. Therefore, ore is ground to an extent that all the

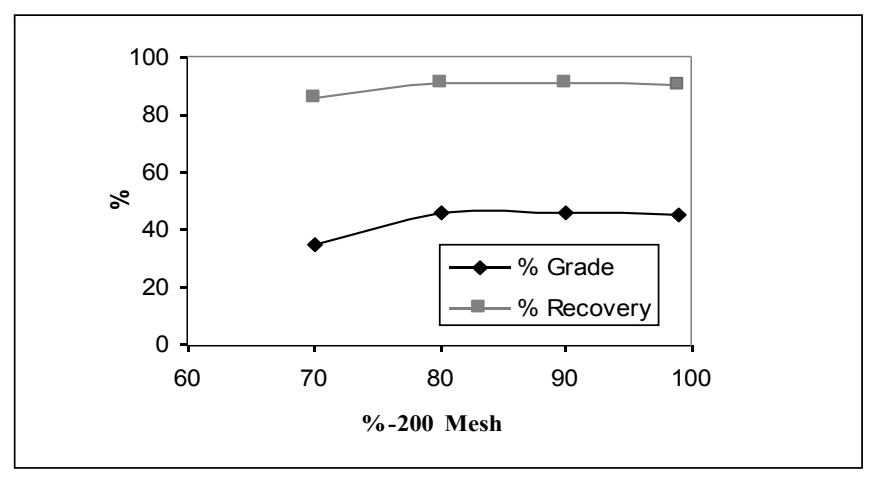

[Conditions: pH of pulp (natural), Pulp density (25\%), Agitation speed $(1000 \mathrm{rpm})$, Lead acetate $(1000 \mathrm{~g} / \mathrm{t})$, Amyl xanthate $(300 \mathrm{~g} / \mathrm{t})$, Pine oil $(50 \mathrm{~g} / \mathrm{t})$, Sodium silicate $(500 \mathrm{~g} / \mathrm{t})$ and Conditioning time $(10 \mathrm{~min})]$

Fig.1. Effect of particle size on grade and recovery of rougher concentrate mineral grains of interest are fairly liberated from the associated gangue minerals at the coarsest possible size avoiding over-grinding (Crozier, 1992). It is obvious from the metallurgical data regarding grain size versus grade and recovery plotted in Fig. 1 that both grade and recovery of antimony concentrate were gradually improved as the particle size was decreased and maximum recovery was obtained at feed size of $80 \%$ passing 200 mesh $(74 \mu \mathrm{m})$. This was considered as optimum feed size and selected for the further study. It is also notable that both grade and recovery sharply decreases on further grinding of ore. It is probably due to the fact that on excessive grinding, the slimes are generated which lowers the grade as well as recovery. The particles in the size below $20 \mu \mathrm{m}$ (slimes) have a deleterious effect on the process of flotation (Parsonage, 1985).

It is clear from the data for \%solids versus grade and recovery given in Fig.2 that increase in pulp density decreases the grade slightly but increases the recovery up to a certain point. The maximum recovery was obtained at $30 \%$ solids beyond which it decreased. Therefore, this value was selected for the remaining study. It seems that higher pulp density $(>30 \%)$ inhibits proper air dispersion and good bubble formation thereby adversely affecting the recovery. It was observed that at cleaning stage of flotation, a pulp density of $20 \%$ produced a concentrate with good grade and recovery. Generally higher recovery at rougher stage is required with minimum losses in tailing, because rougher tailing is discarded. While on the other hand, at cleaning stage of flotation, a lower pulp density was selected to achieve a concentrate of higher grade .

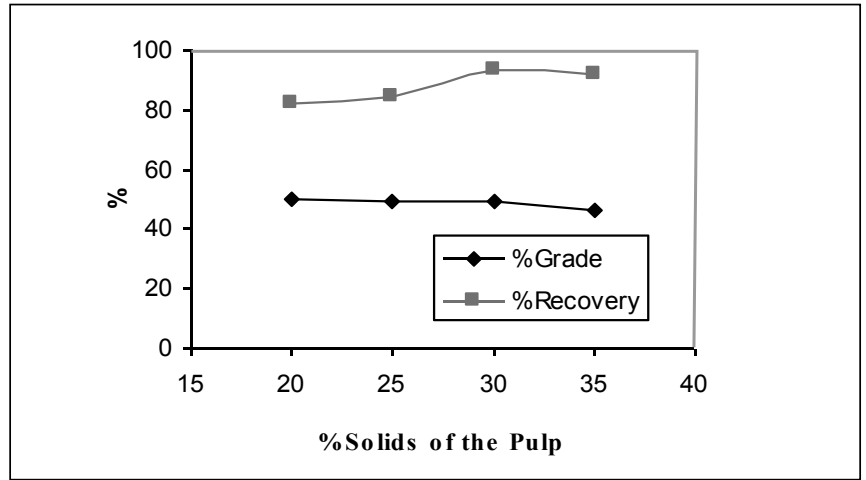

[Conditions: Particle size ( $80 \%-200 \#), \mathrm{pH}$ of pulp (natural), Agitation speed $(1000 \mathrm{rpm})$, Lead acetate $(1000 \mathrm{~g} / \mathrm{t})$, Amyl xanthate $(300 \mathrm{~g} / \mathrm{t})$, Pine oil $(50 \mathrm{~g} / \mathrm{t})$, Sodium silicate $(500 \mathrm{~g} / \mathrm{t})$ and Conditioning time (10min)]

Fig. 2. Effect of pulp density on grade and recovery of rougher concentrate 
A series of flotation tests was conducted in which $\mathrm{pH}$ of pulp was varied from 8.0-9.5. It was adjusted with the help of sodium carbonate. The results obtained at various $\mathrm{pH}$ values (Fig.3) reflect that the grade and recovery increase with increase in $\mathrm{pH}$ from neutral to slightly alkaline medium and then decrease. It was observed that the maximum recovery of antimony concentrate was obtained at a $\mathrm{pH}$ of 9.0. It is also obvious from this figure that a small variation in $\mathrm{pH}$ showed a significant change in grade and recovery. This is probably due to the maximum stability of mineral-xanthate bond in specific $\mathrm{pH}$ value (Wills, 1992).

It is obvious from Fig. 4 that an agitation speed of around $1100 \mathrm{rpm}$ gave better performance at rougher stage. At lower aeration, the recovery decreases but grade is

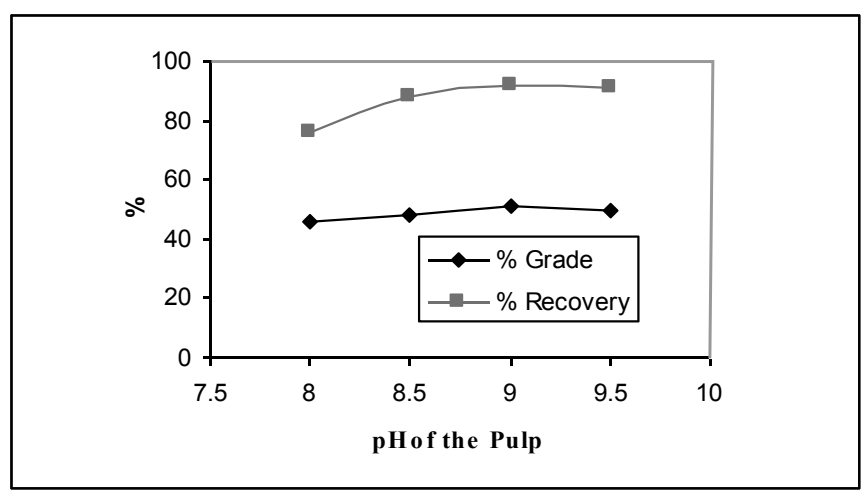

[Conditions: Particle size (80\%-200\#), Pulp density (30\%), Agitation speed $(1000 \mathrm{rpm})$, Lead acetate $(1000 \mathrm{~g} / \mathrm{t})$, Amyl xanthate $(300 \mathrm{~g} / \mathrm{t})$, Pine oil $(50 \mathrm{~g} / \mathrm{t})$, Sodium silicate $(500 \mathrm{~g} / \mathrm{t})$ and Conditioning time $(10 \mathrm{~min})]$

Fig. 3. Effect of $\mathrm{pH}$ on grade and recovery of rougher concentrate

improved slightly. Since it is desirable to have a higher recovery at rougher stage rather than grade so this value was selected. While on the other hand, at cleaning stages, a lower agitation speed of $900 \mathrm{rpm}$ was found to improve the grade. It is due to the fact that on re-grinding, the particle size is further reduced which favour lower rpm.

Xanthates were selected for flotation of stibnite instead of dithiophosphates because they produce better result in alkaline medium. It was found that stibnite mineral does not float satisfactorily with xanthate collector. In order to overcome this problem, it was activated with lead or copper ions. Activation is due to adsorption of lead or copper ions on the crystal lattice of stibnite to form more stable molecules of lead or copper sulphide at the mineral surface. The lead / copper sulphide, so deposited at the mineral surface, reacts readily with xanthate to form insoluble lead/ copper xanthate complex which being

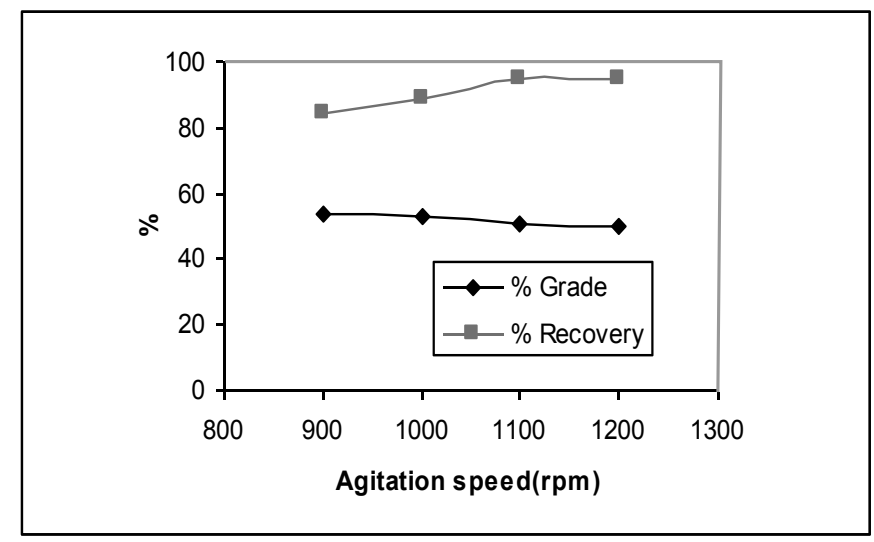

[Conditions: Particle size (80\%-200\#), Pulp density (30\%), pH of pulp (9.0), Lead acetate $(1000 \mathrm{~g} / \mathrm{t})$, Amyl xanthate $(300 \mathrm{~g} / \mathrm{t})$, Pine oil $(50$ $\mathrm{g} / \mathrm{t})$, Sodium silicate $(500 \mathrm{~g} / \mathrm{t})$ and Conditioning time $(10 \mathrm{~min})]$

Fig. 4. Effect of agitation speed (aeration) on grade and recovery of rougher concentrate

hydrophobic, can easily attach with air bubbles (Pen'kov, 2001). Lead acetate and copper sulphate were tried as activator but lead acetate respond well. Results obtained using different quantities of activator (Fig.5) point out that the both grade and recovery increase intensively with increase in the amount of activator up to $1250 \mathrm{~g} / \mathrm{t}$ and further increase is not impressive.

Potassium isopropyl xanthate, isobutyl xanthate and amyl xanthate were attempted as stibnite collector but amyl

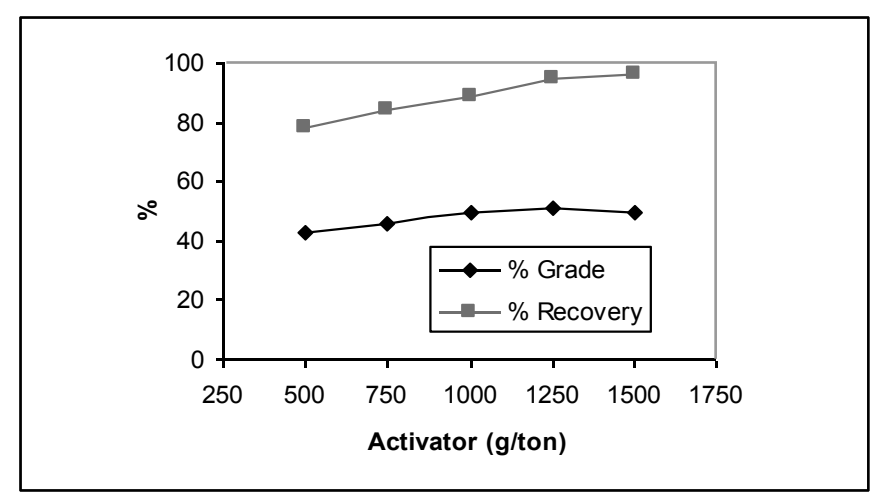

[Conditions: Particle size (80\%-200\#), Pulp density (30\%), Agitation speed (1100rpm), pH of pulp (9.0), Amyl xanthate (300 g/t), Pine oil (50 $\mathrm{g} / \mathrm{t})$, Sodium silicate $(500 \mathrm{~g} / \mathrm{t})$ and Conditioning time $(10 \mathrm{~min})]$

Fig. 5. Effect of activator (lead acetate) on grade and recovery of rougher concentrate

xanthate produced comparatively higher result in term of grade. The amount of potassium amyl xanthate collector used for flotation tests (Fig.6) shows that additions of collector up to $300 \mathrm{~g} / \mathrm{t}$ yielded proportional increases in 
concentrate grade. It is notable on the other hand, that excessive amount of collector (greater than starvation level) adversely affects the grade and recovery probably due to the development of multi-layers of collector on the mineral particles that reduce the selectivity (Wills, 1992).

Pine oil, terpene oil and polypropylene glycol were used as frother but pine oil produced more stable froth. It is apparent from the results of different dosage of frother (pine oil) presented in Fig. 7 that a dosage of $40 \mathrm{~g} / \mathrm{t}$ gives a reasonable grade and recovery and additions greater than it shows no significant improvement in the metallurgy.

Sodium silicate was applied as a regulator to keep down the gangue minerals (quartz, silicates and clay) in the pulp

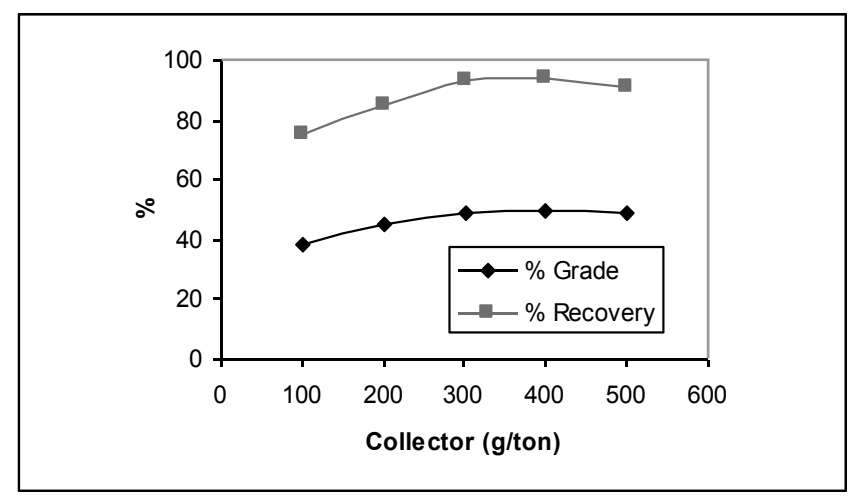

[Conditions: Particle size $(85 \%-200 \#)$, Pulp density $(30 \%)$, Agitation speed (1100rpm), $\mathrm{pH}$ of pulp (9.0), Lead acetate (1250g/t), Pine oil (50 $\mathrm{g} / \mathrm{t})$, Sodium silicate $(500 \mathrm{~g} / \mathrm{t})$ and Conditioning time $(10 \mathrm{~min})]$

Fig. 6. Effect of collector (amyl xanthate) on grade and recovery of rougher concentrate

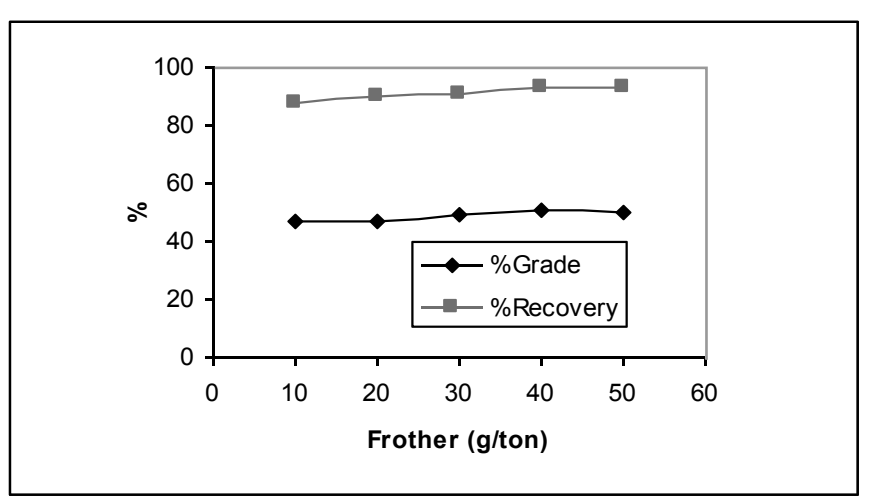

[Conditions: Particle size ( $80 \%-200 \#)$, Pulp density (30\%), Agitation speed (1100rpm), $\mathrm{pH}$ of pulp (9.0), Lead acetate $(1250 \mathrm{~g} / \mathrm{t})$, Amyl xanthate $(300 \mathrm{~g} / \mathrm{t})$, Sodium silicate $(500 \mathrm{~g} / \mathrm{t})$ and Conditioning time (10 $\mathrm{min})]$

Fig. 7. Effect of frother (pine oil) on grade and recovery of rougher concentrate by rendering them hydrophilic. Results obtained using different quantities of depressant (Fig.8) show that grade of the concentrate increases with increase in the concentration of sodium silicate gradually but after $800 \mathrm{~g} / \mathrm{t}$, the recovery begins to decrease. It is probably due to the

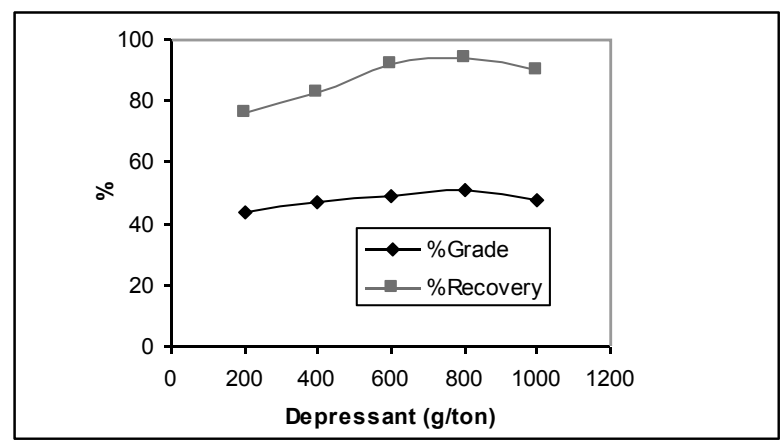

[Conditions: Particle size ( $80 \%-200 \#)$, Pulp density (30\%), Agitation speed (1100rpm), pH of pulp (9.0), Lead acetate $(1250 \mathrm{~g} / \mathrm{t})$, Amyl xanthate $(300 \mathrm{~g} / \mathrm{t})$, Pine oil $(40 \mathrm{~g} / \mathrm{t})$ and Conditioning time (10 $\min )]$

Fig. 8. Effect of depressant (sodium silicate) on grade and recovery of rougher concentrate

reason that some of middling particles are also depressed by excess of sodium silicate. Similarly, rougher concentrates, after regrinding, were cleaned using additional quantity of sodium silicate to depress the further liberated gangue minerals. Sodium cyanide was added as a depressant to depress pyrite in the cleaner circuit. Slight amount of it $(100 \mathrm{~g} / \mathrm{t})$ gave better results at cleaning stage.

It is obvious from the results of different conditioning time (Fig.9) that it has also a significant influence on the grade

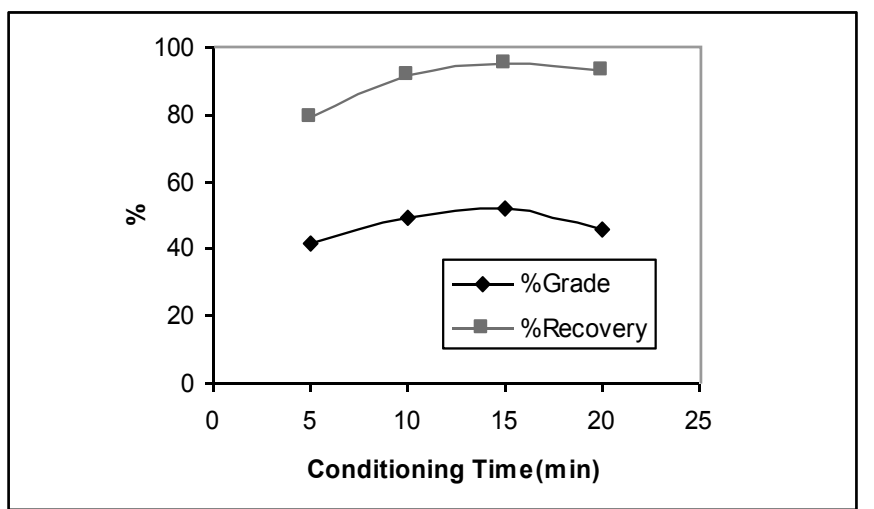

[Conditions: Particle size (80\%-200\#), Pulp density (30\%), agitation speed (1100rpm), pH of pulp (9.0), Lead acetate $(1250 \mathrm{~g} / \mathrm{t})$, Amyl xanthate $(300 \mathrm{~g} / \mathrm{t})$, Pine oil $(40 \mathrm{~g} / \mathrm{t})$ and Sodium silicate $(800 \mathrm{~g} / \mathrm{t})]$

Fig. 9. Effect of conditioning time on grade and recovery of rougher concentrate 
and recovery of the rougher concentrate. A conditioning time of 15 min was found to be sufficient for an optimum grade and recovery. The conditioning period greater than 15 min caused a slight decrease in grade. It seems that a prolonged conditioning time destabilize the mineral-collector complex resulting in lower flotation grade and recovery.

The bench scale flotation tests summarized in Table III. show very encouraging results. The production of a high-grade concentrate containing over $65 \% \mathrm{Sb}$ content in three flotation steps with more than $85 \%$ recovery from an ore initially containing around $20 \%$ metal content is quite acceptable. It is evident from this table that ore can be upgraded up to $52.32 \%$ Sbat rougher flotation stage with $94.87 \%$ recovery. Rougher concentrate is ground to liberate the fine stibnite grains and cleaned to produce a cleaner concentrate having $59.78 \%$ Sb with $90.03 \%$ recoveryusing additional quantity of amyl xanthate collector, sodium silicate and sodium cyanide as regulators in the cleaner circuits. The cleaned concentrate was upgraded to $65.12 \% \mathrm{Sb}$ during a re-cleaner flotation without using additional reagents. The tailings of cleaning stages are circulated, according to its grade, to improve the overall recovery (Fig.10). It is also clear from the chemical analysis of the final concentrate (Table IV.) that the antimony content of the investigated ore has been raised from $20.04 \%$ to $65.12 \%$. It shows that flotation process has been proved successful to reduce the gangue content of the ore significantly.

\section{Conclusion}

It is concluded from the reported results that antimony ore of Qilla Abdullah can be upgraded by three-stage flotation

Table III. Metallurgical balance for antimony ore flotation

\begin{tabular}{lccc}
\hline Products of flotation & Weight (\%) & Grade Sb (\%) & Recovery Sb (\%) \\
\hline Re-Cleaner Concentrate & 26.40 & 65.12 & 85.79 \\
Re-Cleaner Tailings & 3.78 & 22.48 & 4.24 \\
Cleaner Concentrate & 30.18 & 59.78 & 90.03 \\
Cleaner Tailings & 6.16 & 15.74 & 4.84 \\
Rougher Concentrate & 36.34 & 52.32 & 94.87 \\
Rougher Tailings & 63.66 & 1.61 & 5.13 \\
Head Sample & 100 & 20.04 & 100 \\
\hline
\end{tabular}

Table IV. Chemical analysis of final antimony concentrate

\begin{tabular}{lc}
\hline Constituents & Percentage \\
\hline $\mathrm{Sb}$ & 65.12 \\
$\mathrm{~Pb}$ & 1.54 \\
$\mathrm{Fe}$ & 1.16 \\
$\mathrm{~S}$ & 29.88 \\
$\mathrm{SiO}_{2}$ & 0.40 \\
$\mathrm{Al}_{2} \mathrm{O}_{3}$ & 0.62 \\
$\mathrm{BaO}$ & 0.48 \\
$\mathrm{CaO}$ & 0.26 \\
\hline
\end{tabular}




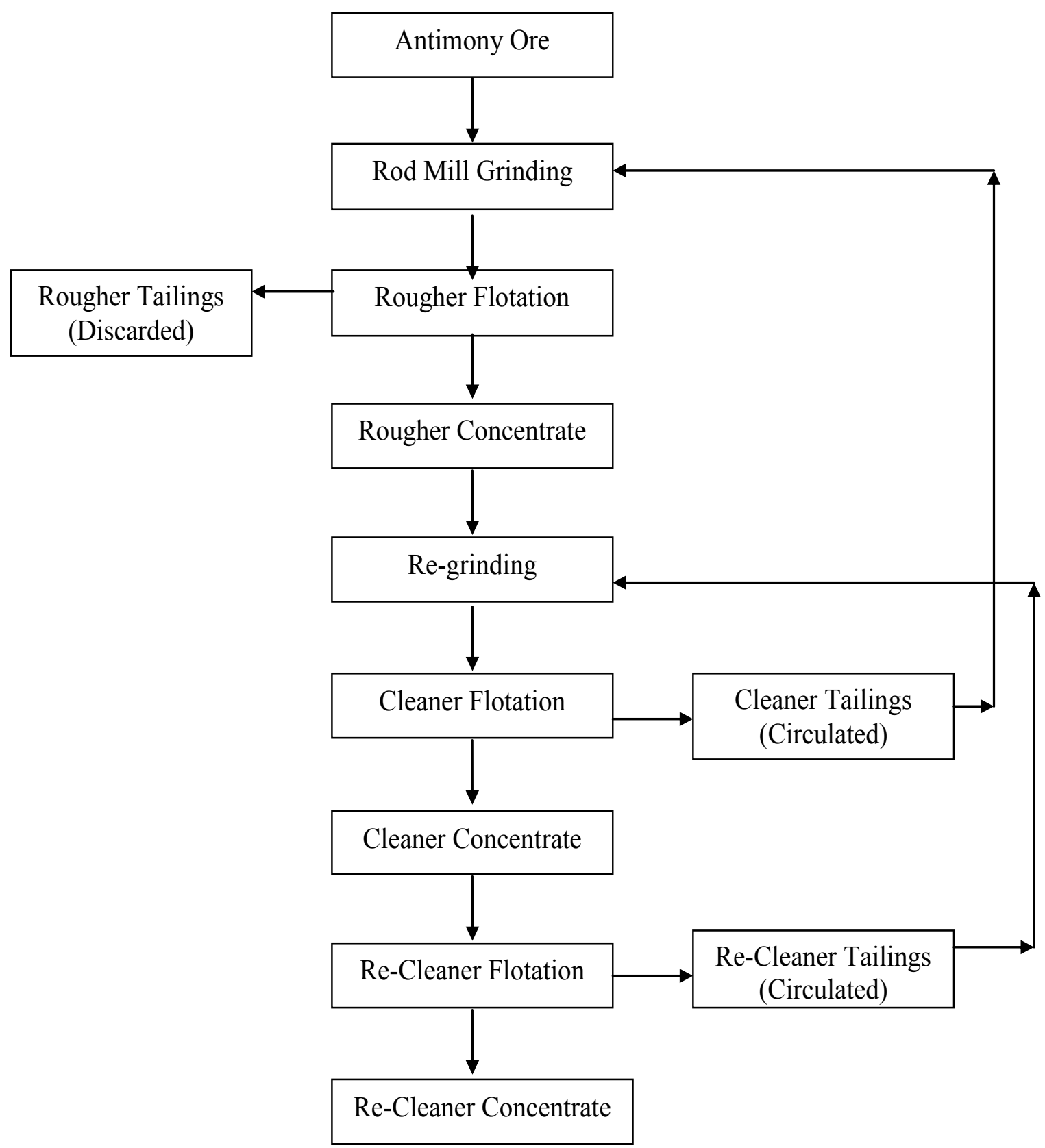

Fig. 10. Flow-sheet developed for the beneficiation of antimony ore of Qilla Abdullah district, Balochistan Province, Pakistan

to produce antimony concentrate of metallurgical grade with an acceptable recovery. The optimum results are achieved at a feed size of $80 \%$ passing $74 \mu \mathrm{m}$, pulp pH of 9 , pulp density of $30 \%$ solids, lead acetate $1250 \mathrm{~g} / \mathrm{t}$, amyl xanthate $300 \mathrm{~g} / \mathrm{t}$, pine oil $40 \mathrm{~g} / \mathrm{t}$, sodium silicate $800 \mathrm{~g} / \mathrm{t}$ and sodium cyanide $100 \mathrm{~g} / \mathrm{t}$ at rougher stage. The higher grade concentrate is obtained after regrinding the rougher concentrate followed by two cleaning operations. The prepared concentrate is suitable for the economical extraction of metal as well as production of various antimony based chemicals.

\section{Acknowledgements}

The authors are highly thankful to Director, Pakistan Mineral Development Corporation (PMDC) for providing 
antimony ore. The assistance of Mr. Wasim Anwar, for the preparation of fresh collector (potassium amyl xanthate) is acknowledged. The contribution of Mr. M. Khalid in the execution of chemical analysis and $\mathrm{Mr}$. Tariq Jamshad in preparation of batches for flotation feed and Mr. Mohammad Akram for electrical and mechanical support is also acknowledged.

\section{References}

Ahmad, Z., (1975), Geology of Mineral Deposits of Balochistan: Records of the Geological Survey of Pakistan, Vol. 36, pp 178

Berger, V.I., (1993), Descriptive and grade and tonnage model for gold-antimony deposits: U.S. Geological Survey Open-File Report 93-194, pp. 24.

Bhatti, M. A., Kazmi, K. R., Nizami, M. S. Anwar, M. S. Habib, M. (2008), Beneficiation. studies on low-grade stibnite ore of Chitral, NWFP, Pakistan, Pakistan Journal of Scientific and Industrial Research, Vol. 51, No.1, pp 45-51.

Blackburn, W. H. (1988). Principles of Mineralogy, pp. 247-248, $1^{\text {st }}$ edition, W. C. Browns Publishers, Iowa, USA.

Crozier, R. D. (1992).Flotation, Theory, Reagents and Ore Testing, $5^{\text {th }}$ edition, Pergamon Press, Oxford, UK. pp.103.
Kursun, I., Arslan, F., Perek, K. T., Gurkan, V. (1994). Beneficiation of EtibankHalikoy antimonite ores by flotation. Prog.Miner.Process. Technol.Ist Int. Miner. Process.Symp. pp. 161-166.

Parsonage, P. G. (1985). "Effects of slimes and colloidal particles on the flotation of galena" in flotation of sulphides minerals, Ed. by Forssberg, K. S. E., Elsevier Science Publishing Company, New York, Vol. 6, pp 111-139.

Pen'kov, N. (2001). Chemical activity of minerals: genetic and technological aspects, Zap. Vseross.Mineral. O-va., Vol. 129, pp 29-37.

Sillitoe, R. H., (1978), Metallogenic evolution of a collisional mountain belt in Pakistan: a preliminary analysis. Journal of the Geological Society, Vol. 135, (4), pp 377-387.

Weiss, N. L. (1985). SME Mineral Processing Hand Book, Society of Mining Engineers, New York, USA. Vol. 2, Section 28, pp. 6-7.

Wills, B.A. (1992).Mineral Processing Technology, $5^{\text {th }}$ edition, Pergamon Press, New York, USA. pp. 501-502,

Received: 17 July 2013; Revised: 28 April 2014; Accepted: 3 June 2014. 